in vivo $35: 2535-2540(2021)$

doi:10.21873/invivo.12535

\title{
Association of Matrix Metalloproteinase-1 Genotypes With Bladder Cancer Risk
}

\author{
CHENG-HSI LIAO ${ }^{1,2,3 *}$, CHIA-WEN TSAI ${ }^{4 *}$, WEN-SHIN CHANG ${ }^{4 *}$, ZHI-HONG WANG ${ }^{5}$, \\ CHI-LI GONG ${ }^{4}$, HSI-CHIN WU ${ }^{4}$, BO-REN WANG ${ }^{1,2,3}$, SHIH-WEI HSU ${ }^{1,2,3}$, \\ WEN-CHIN HUANG ${ }^{1}$, TE-CHUN SHEN ${ }^{4}$ and DA-TIAN BAU ${ }^{1,4,6}$ \\ ${ }^{1}$ Graduate Institute of Biomedical Sciences, China Medical University, Taichung, Taiwan, R.O.C.; \\ ${ }^{2}$ Department of Surgery, Taichung Armed Forces General Hospital, Taichung, Taiwan, R.O.C.; \\ ${ }^{3}$ National Defense Medical Center, Taipei, Taiwan, R.O.C.; \\ ${ }^{4}$ Terry Fox Cancer Research Laboratory, Department of Medical Research, \\ China Medical University Hospital, Taichung, Taiwan, R.O.C.; \\ ${ }^{5}$ Department of Food Nutrition and Health Biotechnology, Asia University, Taichung, Taiwan, R.O.C.; \\ ${ }^{6}$ Department of Bioinformatics and Medical Engineering, Asia University, Taichung, Taiwan, R.O.C.
}

\begin{abstract}
Aim: There is very little literature reporting the association of matrix metalloproteinase-1 (MMP1) with personal susceptibility to bladder cancer. In the current study, we carried out the first examination of the contribution of MMP1 rs1799750 to bladder cancer risk in Taiwanese. Materials and Methods: A total of 375 bladder cancer cases and 375 healthy controls were genotyped for MMPI rs1799750 via polymerase chain reaction-restriction fragment length polymorphism methodology and this was evaluated for association with clinicopathological factors. Results: The frequencies of MMP1 rs $17997502 G / 2 G, 1 G / 2 G$, and $1 G / 1 G$ genotypes were $35.7 \%, 44.8 \%$ and $19.5 \%$ in the group with bladder cancer and $32.5 \%, 46.4 \%$, and $21.1 \%$ in the healthy control group ( $p$ for trend $=0.6362$ ). The odds ratios (ORs) for bladder cancer risk after adjusting for age and gender for those carrying $1 G / 2 G$ and $1 G / 1 G$ genotypes at MMP1 rs 1799750 were $0.88(95 \% C I=0.62-1.24, p=0.4357)$ and 0.83 (95\% CI=0.61-1.26, $p=0.3990$ ), respectively, compared with the wild-type $2 G / 2 G$ genotype. In allelic frequency analysis, the adjusted $O R$ for those carrying the $1 G$ allele at MMP1 rs 1799750 was 0.87 (95\% CI=0.71-1.23, $p=0.3479$ )
\end{abstract}

This article is freely accessible online.

*These Authors contributed equally to this study.

Correspondence to: Da-Tian Bau, Terry Fox Cancer Research Laboratory, Department of Medical Research, China Medical University Hospital, 2 Yuh-Der Road, Taichung, 404 Taiwan, R.O.C. Tel: +886 422053366 (Ext. 5805), e-mail: datian@mail.cmuh.org.tw; artbau2@gmail.com

Key Words: Genotype, MMP1, polymorphism, bladder cancer, Taiwanese. compared to those people carrying a $2 G$ allele. Conclusion: Our findings indicated that the genotypes at MMPI rs 1799750 appear to play little role in determining personal susceptibility to bladder cancer for Taiwanese.

Bladder cancer is the $11^{\text {th }}$ most common cancer, accounting for about $3 \%$ of total cancer deaths globally estimated in 2018 (1). In Taiwan, although the incidence rates of bladder cancer have decreased in recent years, the rapid aging of the population means bladder cancer remains a serious public burden, which has an impact on patients and their relatives, resulting in a massive financial problem for society overall $(2,3)$. From the epidemiological viewpoint, tobacco smoking is believed to be the most critical risk factor for bladder cancer $(4,5)$, in addition to diabetes, exposure to chemicals, contamination in drinking water by arsenic, overuse of traditional Chinese herbs and genetic variations (6-9). A better understanding about genetic predictive markers of bladder cancer is useful for personalized medication and therapy, and reducing the incidence of and death rate by bladder cancer.

In literature, mounting evidence has shown that genetic polymorphisms of matrix metalloproteinases (MMPs) may contribute to the development of bladder cancer (10). MMPs, also named as matrixins, are a large protein family controlling metabolism of the extracellular matrix (11-13). MMPs are closely related to a series of cell behaviors such as proliferation, inflammation, apoptosis, invasion, migration and angiogenesis $(12,13)$. In literature, much evidence has shown that polymorphic variants of MMPs may be associated with personal susceptibility to several types of cancer (14-19).

In 2010, Chuang and colleagues examined the expression of MMPs in 30 bladder neoplasms, finding all were MMP1positive, while other MMPs such as MMP2 and MMP9 were 
not so highly expressed (20). In addition, the overexpression of MMP1 was not correlated with tumor staging nor grading (20). The genomic role of $M M P 1$ remains unclear. In literature, the most commonly studied polymorphic site of MMP1 is rs1799750 which located at $-1,607$ of the promoter of the MMPl gene. The variants at this polymorphic site consist of the insertion $(2 \mathrm{G})$ polymorphism, which in mice was reported to lead to higher transcriptional activity of $M M P 1$, potentially higher levels or rates of collagen breakdown, and higher levels of MMP1 in serum than in mice with $1 \mathrm{G} / 1 \mathrm{G}$ genotype (21). A meta-analysis published in 2012 investigating about 10,000 cancer cases concluded that those MMP1 carrying the rs1799750 2G/2G genotype may have a slightly higher overall metastasis rate (22). In light of all the above, the aim of the current study was to examine the contribution of MMP1 rs1799750 genotype at the promoter region to the risk of bladder cancer in Taiwanese.

\section{Materials and Methods}

Patients with bladder cancer and matched controls. Totally, 375 cases diagnosed with bladder cancer were collected at the China Medical University Hospital in central Taiwan. At the same time, 375 controls matched for age and gender were selected from the Health Examination Cohort. The exclusion criteria for the controls were any previous malignancy, metastasized cancer, and any known familial or genetic diseases. The study design was approved by the Institutional Review Board of the China Medical University Hospital (DMR104-IRB-158). Selective demographic characteristics are summarized in Table I.

Methodology for determination of MMP1 rs1799750 genotype. Genomic DNA from the blood of each participant was extracted, aliquoted and stored at $-80^{\circ} \mathrm{C}$ as routinely conducted (23-25). The $M M P 1$ genotyping methodology was the same as in our recently published article (26). The polymerase chain reaction (PCR) conditions set at My Cycler (Biorad, Hercules, CA, USA) for $M M P 1$ genotyping were initially one cycle at $94^{\circ} \mathrm{C}$ for $5 \mathrm{~min}$; followed by 35 cycles of $94^{\circ} \mathrm{C}$ for $30 \mathrm{~s}, 57^{\circ} \mathrm{C}$ for $30 \mathrm{~s}$ and $72^{\circ} \mathrm{C}$ for $30 \mathrm{~s}$, and a final extension at $72^{\circ} \mathrm{C}$ for $10 \mathrm{~min}$.

Methodology for statistical analysis and determination of significance. The descriptive statistics of bladder cancer cases and healthy controls are shown as the mean and standard deviation (SD) or as percentages. In Table I, Student's $t$-test was adopted for the comparison of ages between the two groups. In Tables I-III, Pearson's chi-square test without Yates' correction was used to compare the distribution of the subgroups. In addition, associations were evaluated using adjusted odds ratios (aORs) with their corresponding $95 \%$ confidence intervals (CIs) with adjustment for age, gender, and personal habits. Differences were identified as being significant when the $p$-value was less than 0.05 .

\section{Results}

Comparison of characteristics among the patient and the healthy control groups. Characteristics such as age, gender,
Table I. Basic characteristics of the 375 bladder cancer cases and 375 healthy controls.

\begin{tabular}{lccc}
\hline Characteristic & Controls $(\mathrm{n}=375)$ & Cases $(\mathrm{n}=375)$ & $p$-Value \\
\hline $\begin{array}{l}\text { Age, years } \\
\quad \text { Mean } \pm \text { SD }\end{array}$ & $62.9 \pm 9.8$ & $61.4 \pm 10.3$ & $0.7315^{\mathrm{a}}$ \\
$\begin{array}{l}\text { Age group } \\
\quad \leq 55 \text { Years }\end{array}$ & $152(40.5 \%)$ & $158(42.1 \%)$ & $0.7108^{\mathrm{b}}$ \\
$\quad>55$ Years & $223(59.5 \%)$ & $217(57.9 \%)$ & \\
Gender & & & \\
$\quad$ Male & $287(76.5 \%)$ & $279(74.4 \%)$ & $0.5525^{\mathrm{b}}$ \\
$\quad$ Female & $88(23.5 \%)$ & $96(25.6 \%)$ & \\
Personal habit & & & \\
$\quad$ Cigarette smoking & $186(49.6 \%)$ & $201(53.6 \%)$ & $0.3063^{\mathrm{b}}$ \\
$\quad$ Alcohol drinking & $176(46.9 \%)$ & $189(50.4 \%)$ & $0.3807^{\mathrm{b}}$ \\
Stage & & & \\
$\quad$ Non-muscle-invasive & & $235(62.7 \%)$ & \\
$\quad$ Muscle-invasive & & $140(37.3 \%)$ & \\
Grade & & & \\
$\quad$ Low & & $224(59.7 \%)$ & \\
$\quad$ High & & &
\end{tabular}

SD: Standard deviation. abased on Student's $t$-test. bbased on chisquared test without Yates' correction.

personal habits, tumor stage and grades for the 375 control and 375 patients with bladder cancer are shown in Table I. Firstly, there was no difference found in the distribution of age and gender between the patient and healthy control groups since these frequencies were matched during recruiting of the non-cancer healthy controls. Secondly, neither smokers nor alcohol drinkers were found to be more frequent in the case group than in the control group (both $p>0.05)$. It showed there was no difference in the frequency of smokers/drinkers between the two groups. Lastly, bladder cancer was mostly of non-muscle-invasive type (62.7\%) and high clinical stage $(59.7 \%)$.

Association of MMP1 rs1799750 genotypes and bladder cancer risk. The genotypic analysis for the MMP1 rs1799750 among the controls and the patients with bladder cancer is shown in Table II. The MMPI rs1799750 genotypic frequency distributions were not significantly different between the control and the case groups ( $p$ for trend $=0.6362$ ) (Table II). In detail, $1 \mathrm{G} / 2 \mathrm{G}$ and $1 \mathrm{G} / 1 \mathrm{G}$ variants at $M M P 1$ rs 1799750 seemed not to be associated with an elevated bladder cancer risk $[\mathrm{aOR}=0.88(95 \% \mathrm{CI}=0.62-1.24)$ and 0.83 (95\% CI=0.61-1.26); $p=0.4357$ and 0.3990 , respectively; Table II]. Compared with those carrying a $2 \mathrm{G}$ allele $(2 \mathrm{G} / 2 \mathrm{G}+1 \mathrm{G} / 2 \mathrm{G})$, homozygosity for the $1 \mathrm{G}$ allele at MMP1 rs1799750 conferred no risk for bladder cancer $(\mathrm{aOR}=0.88$, 95\% CI=0.62-1.27; $p=0.5857$ ) (Table II). Lastly, compared with those homozygous for the $2 \mathrm{G}$ allele, the analytic results still showed that carrying a $1 \mathrm{G}$ allele $(1 \mathrm{G} / 1 \mathrm{G}+1 \mathrm{G} / 2 \mathrm{G})$ at MMP1 rs1799750 did not alter bladder cancer risk 
Table II. Distributions of matrix metalloproteinase-1 (MMP1) rs1799750 genotypic frequencies among patients with bladder cancer and healthy controls.

\begin{tabular}{|c|c|c|c|c|}
\hline MMP1 & Bladder cancer, n (\%) & Controls, n (\%) & Adjusted OR $(95 \% \mathrm{CI})^{\mathrm{a}}$ & $p$-Value ${ }^{\mathrm{b}}$ \\
\hline \multicolumn{5}{|l|}{ rs1799750 } \\
\hline $2 \mathrm{G} / 2 \mathrm{G}$ & $134(35.7)$ & $122(32.5)$ & 1.00 (Reference) & \\
\hline $1 \mathrm{G} / 2 \mathrm{G}$ & $168(44.8)$ & $174(46.4)$ & $0.88(0.62-1.24)$ & 0.4357 \\
\hline $1 \mathrm{G} / 1 \mathrm{G}$ & $73(19.5)$ & $79(21.1)$ & $0.83(0.61-1.26)$ & 0.3990 \\
\hline$P_{\text {trend }}$ & & & & 0.6362 \\
\hline $\mathrm{P}_{\mathrm{HWE}}$ & & & & 0.2482 \\
\hline \multicolumn{5}{|l|}{ Carrier comparison } \\
\hline $2 \mathrm{G} / 2 \mathrm{G}+1 \mathrm{G} / 2 \mathrm{G}$ & $302(80.5)$ & $296(78.9)$ & 1.00 (Reference) & \\
\hline $1 \mathrm{G} / 1 \mathrm{G}$ & $73(19.5)$ & $79(21.1)$ & $0.88(0.62-1.27)$ & 0.5857 \\
\hline $2 \mathrm{G} / 2 \mathrm{G}$ & $134(35.7)$ & $122(32.5)$ & 1.00 (Reference) & \\
\hline $1 \mathrm{G} / 1 \mathrm{G}+1 \mathrm{G} / 2 \mathrm{G}$ & $241(64.3)$ & $253(67.5)$ & $0.86(0.65-1.18)$ & 0.3554 \\
\hline
\end{tabular}

CI: Confidence interval; OR: odds ratio; $\mathrm{P}_{\mathrm{HWE}}$ : $p$-value under Hardy-Weinberg equilibrium ${ }^{\text {aData }}$ were adjusted for age, gender, and personal habits. bBased on chi-square test without Yates' correction.

Table III. Allelic frequencies for matrix metalloproteinase-1 (MMP1) rs1799750 polymorphism among patients with bladder cancer and healthy controls.

\begin{tabular}{lcccc}
\hline MMP1 Allele & Bladder cancer, $\mathrm{n}(\%)$ & Controls, $\mathrm{n}(\%)$ & ${\text { Adjusted OR }(95 \% \mathrm{CI})^{\mathrm{a}}}$ & $p$-Value \\
\hline $\mathrm{G}$ & $436(58.1)$ & $418(55.7)$ & 1.00 (Reference) & \\
$1 \mathrm{G}$ & $314(41.9)$ & $332(44.3)$ & $0.87(0.71-1.23)$ & 0.3479 \\
\hline
\end{tabular}

CI: Confidence interval; OR: odds ratio. 'Data were adjusted for age gender, and personal habits. 'bBased on chi-square test without Yates' correction.

$(\mathrm{aOR}=0.86,95 \% \quad \mathrm{CI}=0.65-1.18 ; p=0.3554) \quad$ (Table II). Overall, MMP1 rs1799750 seemed to have no direct contribution to the risk of bladder cancer.

Bladder cancer risk according to MMP1 promoter allelic frequencies. The distributions of alleles for MMPI rs1799750 among the patients with bladder cancer and healthy controls are shown in Table III. Consistent with the findings in Table II, analysis of allelic frequencies showed that the $1 \mathrm{G}$ allele at $M M P 1$ rs1799750 was not significantly associated with the risk of bladder cancer in Taiwan $(p=0.3479$, adjusted $\mathrm{OR}=0.87,95 \% \mathrm{CI}=0.71-1.23)$ (Table III). In detail, the percentages of variant allelic frequencies in the groups of cases and controls were $41.9 \%$ and $44.3 \%$, respectively (Table III). The results of analysis of MMPI rs1799750 genotypes after stratifying by age, gender, smoking and alcohol consumption status showed no associations at all (all $p>0.05$, data not shown). Clinically, there was no significant difference in distributions between different stages and grades (both $p>0.05$, data not shown).

\section{Discussion}

One of the major components of the extracellular matrix is collagen, the enzymatic substrate of MMP1. In esophageal and colorectal cancer tissues, MMP1 has been shown to be overexpressed and associated with higher risk of death $(27,28)$. As early as 1979 , a pilot study showed that muscle-invasive bladder cancer tissues have higher collagenase activity as their non-invasive counterparts (29). Later MMP1 was detected in the urine of patients with bladder cancer for the first time, and its concentration was found to be significantly increased in urine from patients with higher stage and grade (30). Elevated MMP1 has also been associated with poor survival of patients with bladder cancer (31). Notably, it has been reported that MMP1 was overexpressed in all tissues of fresh-prepared samples from patients with bladder cancer $(n=30)$, while the overexpression of MMP1 was not correlated with tumor staging nor grading (20). It is hypothesized that inhered genomic variations may determine personal susceptibility to bladder cancer initiation, progression, invasion and metastasis.

In the literature, associations of $M M P 1$ genotypes have been examined among many types of cancer, such as lung $(32,33)$, breast $(34-36)$, oral $(37)$, colorectal $(38,39)$, gastric (40-42), endometrial (43), cervical $(44,45)$, prostate $(17,46)$, and ovarian $(47,48)$, in addition to bladder cancer (49-52). Although there were several studies investigating the association of MMP1 genotypes with bladder cancer, the results were inconclusive and the total sample size is far from convincing, which we discuss later. 
in vivo $35: 2535-2540(2021)$

Table IV. A concise summary of literature regarding the association of matrix metalloproteinase-1 (MMP1) rs1799750 genotype with bladder cancer risk.

\begin{tabular}{|c|c|c|c|c|c|}
\hline Authors (Ref) & Year published & Population & Controls, $\mathrm{n}$ & Cases, $\mathrm{n}$ & Highlighted findings \\
\hline Kader et al. (50) & 2006 & Caucasian & 560 & 560 & $\begin{array}{c}\text { MMP1 rs1799750 genotype is not associated } \\
\text { with bladder cancer risk }\end{array}$ \\
\hline Tasci et al. (49) & 2007 & Turkish & 94 & 102 & $\begin{array}{l}2 \mathrm{G} \text { Allele is associated with increased bladder cancer risk } \\
\text { especially among smokers }\end{array}$ \\
\hline Srivastava et al. (51) & 2010 & Indian & 200 & 200 & $\begin{array}{c}2 \mathrm{G} \text { Allele is associated with increased bladder cancer risk } \\
\text { especially among smokers }\end{array}$ \\
\hline Wieczorek et al. (52) & 2013 & Polish & 199 & 241 & $\begin{array}{c}\text { 2G Allele is associated with increased bladder cancer risk } \\
\text { especially among smokers }\end{array}$ \\
\hline Current & & Taiwanese & 375 & 375 & $\begin{array}{l}\text { MMP1 rs1799750 genotype is not associated with } \\
\text { bladder cancer risk, and no increased risk among smokers }\end{array}$ \\
\hline
\end{tabular}

In the present study, it was found that the $1 \mathrm{G}$ allele of MMP1 rs1799750 was not significantly associated with risk of bladder cancer (Tables II and III). In addition, MMPI rs 1799750 genotypes were not associated with age, gender, nor smoking and alcohol consumption behaviors (data not shown). Compared with previous studies, our samples are more genetically conserved (all Taiwanese) and representative (375 patients with bladder cancer and 375 healthy controls). We have summarized previous articles on $M M P 1$ in bladder cancer in Table IV. Our findings are consistent with that reported by Kader and colleagues (50) but not with others with relatively limited samples (49-52). There may be ethnic variations among the reports, and more investigations are needed. Another limitation of the study is that we did not measure the phenotypic status of the participants, and have no understanding the correlation of $1 \mathrm{G}$ allele at MMP1 rs1799750 and transcriptional activity. In addition, the associations between the expression level of MMP1 with other parameters, such as age, gender, smoking or alcohol consumption status, or tumor stage and grade, are not available. Chuang and colleagues analyzed 30 samples, finding that MMP2 was correlated with high-grade tumors and MMP9 was correlated with advanced tumor stage. However, the expression of MMP1, MMP3, and tissue inhibitor of metalloproteinase-1 and -2 was not correlated with either tumor staging or grading (20). Their data are valuable, however, there is no genotypephenotype correlation.

In conclusion, this study examined the genotypic patterns of MMP1 rs1799750 among Taiwanese people. Neither MMP1 $1 \mathrm{G}$ nor $2 \mathrm{G}$ allele appeared to contribute to susceptibility of bladder cancer. Some other markers, for instance single nucleotide polymorphisms on other MMPs may play more critical roles than $M M P 1$, and further investigations are needed to elucidate their role in bladder cancer etiology.

\section{Conflicts of Interest}

The Authors have declared no conflicts of interest.

\section{Authors' Contributions}

Research design: Liao CH, Tsai CW and Chang WS; patient and questionnaire summaries: Liao $\mathrm{CH}, \mathrm{Wu} \mathrm{HC}$ and Wang $\mathrm{BR}$; experimental work: Gong CL, Chang WS and Wang ZH; statistical analysis: Hsu SW, Huang WC and Shen TC; article writing: Tsai $\mathrm{CW}$ and Bau DT; review and revision: Bau DT.

\section{Acknowledgements}

The Authors thank Tissue-bank of China Medical University Hospital for technical assistance in data and sample collection. This study was supported by the Taichung Armed Forces General Hospital to Dr. Liao (TCAFGH-D-109021) and by Asia University and China Medical University Hospital to Drs. Shen and Gong (CMU109-ASIA-04).

\section{References}

1 Cai Z and Liu Q: Understanding the Global Cancer Statistics 2018: implications for cancer control. Sci China Life Sci 64(6): 10171020, 2021. PMID: 31463738. DOI: 10.1007/s11427-019-9816-1

2 Chang WS, Tsai CW, Ji HX, Wu HC, Chang YT, Lien CS, Liao WL, Shen WC, Tsai $\mathrm{CH}$ and Bau DT: Associations of cyclooxygenase 2 polymorphic genotypes with bladder cancer risk in Taiwan. Anticancer Res 33(12): 5401-5405, 2013. PMID: 24324075.

3 Chang WS, Liao CH, Tsai CW, Hu PS, Wu HC, Hsu SW, Hsiao $\mathrm{CL}$, Hsu CH, Hung YW and Bau DT: Association of enhancer of Zeste 2 (EZH2) genotypes with bladder cancer risk in Taiwan. Anticancer Res 36(9): 4509-4514, 2016. PMID: 27630289. DOI: 10.21873/anticanres.10997

4 Cumberbatch MG, Rota M, Catto JW and La Vecchia C: The role of tobacco smoke in bladder and kidney carcinogenesis: A comparison of exposures and meta-analysis of incidence and mortality risks. Eur Urol 70(3): 458-466, 2016. PMID: 26149669. DOI: 10.1016/j.eururo.2015.06.042

5 van Osch FH, Jochems SH, van Schooten FJ, Bryan RT and Zeegers MP: Quantified relations between exposure to tobacco smoking and bladder cancer risk: a meta-analysis of 89 observational studies. Int J Epidemiol 45(3): 857-870, 2016. PMID: 27097748. DOI: 10.1093/ije/dyw044 
6 Lai MN, Wang SM, Chen PC, Chen YY and Wang JD: Population-based case-control study of Chinese herbal products containing aristolochic acid and urinary tract cancer risk. J Natl Cancer Inst 102(3): 179-186, 2010. PMID: 20026811. DOI: 10.1093/jnci/djp467

7 Yang HY, Wang JD, Lo TC and Chen PC: Occupational exposure to herbs containing aristolochic acids increases the risk of urothelial carcinoma in Chinese herbalists. J Urol 189(1): 4852, 2013. PMID: 23164394. DOI: 10.1016/j.juro.2012.08.090

8 Poon SL, Huang MN, Choo Y, McPherson JR, Yu W, Heng HL, Gan A, Myint SS, Siew EY, Ler LD, Ng LG, Weng WH, Chuang CK, Yuen JS, Pang ST, Tan P, Teh BT and Rozen SG: Mutation signatures implicate aristolochic acid in bladder cancer development. Genome Med 7(1): 38, 2015. PMID: 26015808. DOI: 10.1186/s13073-015-0161-3

9 Jhuang JR, Chiang CJ, Su SY, Yang YW and Lee WC: Reduction in the incidence of urological cancers after the ban on Chinese herbal products containing aristolochic acid: An interrupted time-series analysis. Sci Rep 9(1): 19860, 2019. PMID: 31882686. DOI: 10.1038/s41598-019-56394-y

10 Kader AK, Liu J, Shao L, Dinney CP, Lin J, Wang Y, Gu J, Grossman $\mathrm{HB}$ and $\mathrm{Wu} \mathrm{X}$ : Matrix metalloproteinase polymorphisms are associated with bladder cancer invasiveness. Clin Cancer Res 13(9): 2614-2620, 2007. PMID: 17473191. DOI: 10.1158/1078-0432.CCR-06-1187

11 de Souza AP, Trevilatto PC, Scarel-Caminaga RM, Brito RB and Line SR: MMP-1 promoter polymorphism: association with chronic periodontitis severity in a Brazilian population. J Clin Periodontol 30(2): 154-158, 2003. PMID: 12622858. DOI: 10.1034/j.1600-051x.2003.300202.x

12 Egeblad $M$ and Werb Z: New functions for the matrix metalloproteinases in cancer progression. Nat Rev Cancer 2(3): 161-174, 2002. PMID: 11990853. DOI: $10.1038 / \mathrm{nrc} 745$

13 Van Lint $\mathrm{P}$ and Libert C: Chemokine and cytokine processing by matrix metalloproteinases and its effect on leukocyte migration and inflammation. J Leukoc Biol 82(6): 1375-1381, 2007. PMID: 17709402. DOI: 10.1189/jlb.0607338

14 Tsai CW, Chang WS, Gong CL, Shih LC, Chen LY, Lin EY, Li HT, Yen ST, Wu CN and Bau DT: Contribution of matrix metallopeptidase-1 genotypes, smoking, alcohol drinking and areca chewing to nasopharyngeal carcinoma susceptibility. Anticancer Res 36(7): 3335-3340, 2016. PMID: 27354591.

15 Sun KT, Tsai CW, Chang WS, Shih LC, Chen LY, Tsai MH, Ji HX, Hsiao CL, Liu YC, Li CY and Bau DT: The contribution of matrix metalloproteinase-1 genotype to oral cancer susceptibility in Taiwan. In Vivo 30(4): 439-444, 2016. PMID: 27381606.

$16 \mathrm{Wu}$ MH, Tzeng HE, Wu CN, Yueh TC, Peng YC, Tsai CH, Wang YC, Ke TW, Pei JS, Chang WS, Tsai CW and Bau DT: Association of matrix metalloproteinase-9 rs3918242 promoter genotypes with colorectal cancer risk. Anticancer Res 39(12): 6523-6529, 2019. PMID: 31810917. DOI: 10.21873/anticanres. 13867

17 Liao CH, Wu HC, Hu PS, Hsu SW, Shen TC, Hsia TC, Chang WS, Tsai CW and Bau DT: The association of matrix metalloproteinase-1 promoter polymorphisms with prostate cancer in Taiwanese patients. Anticancer Res 38(7): 3907-3911, 2018. PMID: 29970511. DOI: 10.21873/anticanres.12675

18 Yueh TC, Wu CN, Hung YW, Chang WS, Fu CK, Pei JS, Wu MH, Lai YL, Lee YM, Yen ST, Li HT, Tsai CW and Bau DT: The contribution of MMP-7 genotypes to colorectal cancer susceptibility in Taiwan. Cancer Genomics Proteomics 15(3): 207-212, 2018. PMID: 29695403. DOI: $10.21873 / \mathrm{cgp} .20079$

19 Shen TC, Chang WS, Tsai CW, Chao CY, Lin YT, Hsiao CL, Hsu CL, Chen WC, Hsia TC and Bau DT: The contribution of matrix metalloproteinase-1 promoter genotypes in Taiwan lung cancer risk. Anticancer Res 38(1): 253-257, 2018. PMID: 29277780. DOI: 10.21873/anticanres.12215

20 Chuang CK, Pang ST, Chuang TJ and Liao SK: Profiling of matrix metalloproteinases and tissue inhibitors of metalloproteinases proteins in bladder urothelial carcinoma. Oncol Lett 1(4): 691-695, 2010. PMID: 22966365. DOI: 10.3892/ol_00000121

21 Tower GB, Coon CI and Brinckerhoff CE: The 2G single nucleotide polymorphism (SNP) in the MMP-1 promoter contributes to high levels of MMP-1 transcription in MCF7/ADR breast cancer cells. Breast Cancer Res Treat 82(2): 7582, 2003. PMID: 14692651. DOI: 10.1023/B:BREA. $0000003948.14026 .7 \mathrm{c}$

22 Liu D, Guo H, Li Y, Xu X, Yang K and Bai Y: Association between polymorphisms in the promoter regions of matrix metalloproteinases (MMPs) and risk of cancer metastasis: a meta-analysis. PLoS One 7(2): e31251, 2012. PMID: 22348060. DOI: 10.1371/journal.pone.0031251

23 Chen GL, Wang SC, Shen TC, Chang WS, Lin C, Hsia TC, Bau DT and Tsai CW: Significant association of chitinase 3-like 1 genotypes to asthma risk in Taiwan. In Vivo 35(2): 799-803, 2021. PMID: 33622872. DOI: 10.21873/invivo.12320

24 Chen KY, Chien WC, Liao JM, Tsai CW, Chang WS, Su CH, Hsu SW, Wang HC and Bau DT: Contribution of interleukin-10 genotype to triple negative breast cancer risk. Anticancer Res 41(5): 2451-2457, 2021. PMID: 33952470. DOI: 10.21873/ anticanres. 15020

25 Wu CN, Chang WS, Shih LC, Wang YC, Lee HT, Yu CC, Wang $\mathrm{ZH}$, Mong MC, Hsia TC, Tsai CW and Bau DT: Interaction of DNA repair gene XPC with smoking and betel quid chewing behaviors of oral cancer. Cancer Genomics Proteomics 18(3 Suppl): 441-449, 2021. PMID: 33994366. DOI: 10.21873/ cgp. 20270

26 Tsai CB, Hsia NY, Wang YC, Wang ZH, Chin YT, Huang TL, Yu CC, Chang WS, Tsai CW, Yin MC and Bau DT: The significant association of $M M P-1$ genotypes with Taiwan pterygium. Anticancer Res 40(2): 703-707, 2020. PMID: 32014911. DOI: 10.21873/anticanres.14000

27 Murray GI, Duncan ME, O’Neil P, Melvin WT and Fothergill JE: Matrix metalloproteinase-1 is associated with poor prognosis in colorectal cancer. Nat Med 2(4): 461-462, 1996. PMID: 8597958. DOI: $10.1038 / \mathrm{nm} 0496-461$

28 Murray GI, Duncan ME, O’Neil P, McKay JA, Melvin WT and Fothergill JE: Matrix metalloproteinase-1 is associated with poor prognosis in oesophageal cancer. J Pathol 185(3): 256-261, 1998. PMID: 9771478. DOI: 10.1002/(SICI)1096-9896(199807) 185:3<256::AID-PATH115>3.0.CO;2-A

29 Wirl G and Frick J: Collagenase-a marker enzyme in human bladder cancer? Urol Res 7(2): 103-108, 1979. PMID: 224548. DOI: $10.1007 / \mathrm{BF} 00254689$

30 Nutt JE, Mellon JK, Qureshi K and Lunec J: Matrix metalloproteinase- 1 is induced by epidermal growth factor in human bladder tumour cell lines and is detectable in urine of patients with bladder tumours. Br J Cancer 78(2): 215-220, 1998. PMID: 9683296. DOI: 10.1038/bjc.1998.467 
31 Durkan GC, Nutt JE, Rajjayabun PH, Neal DE, Lunec J and Mellon JK: Prognostic significance of matrix metalloproteinase1 and tissue inhibitor of metalloproteinase- 1 in voided urine samples from patients with transitional cell carcinoma of the bladder. Clin Cancer Res 7(11): 3450-3456, 2001. PMID: 11705862.

32 Liu L, Wu J, Wu C, Wang Y, Zhong R, Zhang X, Tan W, Nie S, Miao $X$ and Lin D: A functional polymorphism $(-16071 \mathrm{G} \rightarrow 2 \mathrm{G})$ in the matrix metalloproteinase- 1 promoter is associated with development and progression of lung cancer. Cancer 117(22): 5172-5181, 2011. PMID: 21523769. DOI: 10.1002/cncr.26154

33 Heist RS, Marshall AL, Liu G, Zhou W, Su L, Neuberg D, Lynch TJ, Wain J and Christiani DC: Matrix metalloproteinase polymorphisms and survival in stage I non-small cell lung cancer. Clin Cancer Res 12(18): 5448-5453, 2006. PMID: 17000679. DOI: 10.1158/1078-0432.CCR-06-0262

34 Balkhi S, Mashayekhi F, Salehzadeh A and Saedi HS: Matrix metalloproteinase (MMP)-1 and MMP-3 gene variations affect MMP-1 and -3 serum concentration and associates with breast cancer. Mol Biol Rep 47(12): 9637-9644, 2020. PMID: 33170424. DOI: $10.1007 / \mathrm{s} 11033-020-05962-\mathrm{x}$

35 Hsiao CL, Liu LC, Shih TC, Lai YL, Hsu SW, Wang HC, Pan SY, Shen TC, Tsai CW, Chang WS, Su CH, Way TD, Chung JG and Bau DT: The association of Matrix Metalloproteinase-1 promoter polymorphisms with breast cancer. In Vivo 32(3): 487491, 2018. PMID: 29695550. DOI: 10.21873/invivo.11265

36 Padala C, Tupurani MA, Puranam K, Gantala S, Shyamala N, Kondapalli MS, Gundapaneni KK, Mudigonda S, Galimudi RK, Kupsal K, Nanchari SR, Chavan U, Chinta SK, Mukta S, Satti $\mathrm{V}$ and Hanumanth SR: Synergistic effect of collagenase-1 (MMP1), stromelysin-1 (MMP3) and gelatinase-B (MMP9) gene polymorphisms in breast cancer. PLoS One 12(9): e0184448, 2017. PMID: 28961241. DOI: 10.1371/journal.pone.0184448

37 Vairaktaris E, Serefoglou Z, Avgoustidis D, Yapijakis C, Critselis E, Vylliotis A, Spyridonidou S, Derka S, Vassiliou S, Nkenke E and Patsouris E: Gene polymorphisms related to angiogenesis, inflammation and thrombosis that influence risk for oral cancer. Oral Oncol 45(3): 247-253, 2009. PMID: 18674955. DOI: 10.1016/j.oraloncology.2008.05.003

38 Wu MH, Yueh TC, Chang WS, Tsai CW, Fu CK, Yang MD, Yu $\mathrm{CC}$ and Bau DT: Contribution of Matrix Metalloproteinase-1 genotypes to colorectal cancer in Taiwan. Cancer Genomics Proteomics 18(3): 245-251, 2021. PMID: 33893077. DOI: $10.21873 / \operatorname{cgp} .20255$

39 de Lima JM, de Souza LG, da Silva ID and Forones NM: Ecadherin and metalloproteinase- 1 and -7 polymorphisms in colorectal cancer. Int J Biol Markers 24(2): 99-106, 2009. PMID: 19634113.

40 Devulapalli K, Bhayal AC, Porike SK, Macherla R, Akka J, Nallari P and Ananthapur V: Role of interstitial collagenase gene promoter polymorphism in the etiology of gastric cancer. Saudi J Gastroenterol 20(5): 309-314, 2014. PMID: 25253367. DOI: 10.4103/1319-3767.141693

41 Dedong H, Bin Z, Peisheng S, Hongwei X and Qinghui Y: The contribution of the genetic variations of the matrix metalloproteinase-1 gene to the genetic susceptibility of gastric cancer. Genet Test Mol Biomarkers 18(10): 675-682, 2014. PMID: 25148204. DOI: 10.1089/gtmb.2014.0117

42 Song YX, Zhou X, Wang ZN, Gao P, Li AL, Liang JW, Zhu JL, $\mathrm{Xu}$ YY and $\mathrm{Xu}$ HM: The association between individual SNPs or haplotypes of matrix metalloproteinase 1 and gastric cancer susceptibility, progression and prognosis. PLoS One 7(5): e38002, 2012. PMID: 22655095. DOI: 10.1371/journal. pone. 0038002

43 Beeghly-Fadiel A, Xiang YB, Deming SL, Long JR, Xu WH, Cai Q, Zheng W and Shu XO: No association between matrix metalloproteinase (MMP)-1, MMP-3, and MMP-7 SNPs and endometrial cancer risk. Cancer Epidemiol Biomarkers Prev 18(6): 1925-1928, 2009. PMID: 19435861. DOI: 10.1158/10559965.EPI-09-0244

44 Lai HC, Chu CM, Lin YW, Chang CC, Nieh S, Yu MH and Chu TY: Matrix metalloproteinase 1 gene polymorphism as a prognostic predictor of invasive cervical cancer. Gynecol Oncol 96(2): 314-319, 2005. PMID: 15661214. DOI: 10.1016/j.ygyno. 2004.09.065

$45 \mathrm{Ju}$ W, Kang S, Kim JW, Park NH, Song YS, Kang SB and Lee HP: Promoter polymorphism in the matrix metalloproteinase-1 and risk of cervical cancer in Korean women. Cancer Lett 217(2): 191-196, 2005. PMID: 15617836. DOI: 10.1016/j.canlet. 2004.08 .032

46 Albayrak S, Cangüven O, Göktaş C, Aydemir H and Köksal V: Role of MMP-1 $1 \mathrm{G} / 2 \mathrm{G}$ promoter gene polymorphism on the development of prostate cancer in the Turkish population. Urol Int 79(4): 312-315, 2007. PMID: 18025848. DOI: 10.1159/ 000109715

47 Ju W, Kim JW, Park NH, Song YS, Kim SC, Kang SB and Lee HP: Matrix metalloproteinase-1 promoter polymorphism and epithelial ovarian cancer: does ethnicity matter? J Obstet Gynaecol Res 33(2): 155-160, 2007. PMID: 17441888. DOI: 10.1111/j.1447-0756.2007.00511.x

48 Li Y, Jin X, Kang S, Wang Y, Du H, Zhang J, Guo W, Wang N and Fang S: Polymorphisms in the promoter regions of the matrix metalloproteinases-1, $-3,-7$, and -9 and the risk of epithelial ovarian cancer in China. Gynecol Oncol 101(1): 9296, 2006. PMID: 16278009. DOI: 10.1016/j.ygyno.2005.09.058

49 Tasci AI, Tugcu V, Ozbek E, Ozbay B, Simsek A and Koksal V: A single-nucleotide polymorphism in the matrix metalloproteinase-1 promoter enhances bladder cancer susceptibility. BJU Int 101(4): 503-507, 2008. PMID: 17986285. DOI: $10.1111 / \mathrm{j} .1464-410 X .2007 .07315 . \mathrm{x}$

50 Kader AK, Shao L, Dinney CP, Schabath MB, Wang Y, Liu J, $\mathrm{Gu} \mathrm{J}$, Grossman $\mathrm{HB}$ and $\mathrm{Wu} \mathrm{X}$ : Matrix metalloproteinase polymorphisms and bladder cancer risk. Cancer Res 66(24): 11644-11648, 2006. PMID: 17178858. DOI: 10.1158/00085472.CAN-06-1212

51 Srivastava P, Gangwar R, Kapoor R and Mittal RD: Bladder cancer risk associated with genotypic polymorphism of the matrix metalloproteinase-1 and 7 in North Indian population. Dis Markers 29(1): 37-46, 2010. PMID: 20826916. DOI: 10.3233/ DMA-2010-0724

52 Wieczorek E, Reszka E, Jablonowski Z, Jablonska E, Krol MB, Grzegorczyk A, Gromadzinska J, Sosnowski M and Wasowicz W: Genetic polymorphisms in matrix metalloproteinases (MMPs) and tissue inhibitors of MPs (TIMPs), and bladder cancer susceptibility. BJU Int 112(8): 1207-1214, 2013. PMID: 23819551. DOI: 10.1111/bju.12230

Received June 14, 2021

Revised July 3, 2021

Accepted July 6, 2021 